\title{
Coagulation Studies After Transfusion of Hydroxyethyl Starch Protected Frozen Blood in Primates
}

\author{
L. Weatherbee, H. H. Spencer, C. T. Knorpp, S. M. Lindenauer, \\ P. W. Gikas, and N. W. Thompson \\ From the Veterans Administration Hospital, and University of Michigan Medical Center, \\ Aun Arbor, Michigan
}

\begin{abstract}
This-study evaluates the effects of the transfusion of frozen-thawed blood protected by hydroxyethyl starch (HES) on shocked monkeys. Particular attention is directed toward the study of coagulation in view of previous reports of coagulopathies caused by hydroxyethyl starch. In vivo studies were done in 13 shocked monkeys that received either homologous or autologous blood which had been frozen and thawed with 14 per cent HES as the cryoprotective agent. Multiple coagulation studies were obtained on the monkeys, and histopathological evaluations were performed. There was no evidence of increased bleeding or bleeding tendencies in the monkeys transfused with HES preserved blood. Serum chemistry values were not signifcantly altered in animals that received blood pre served by HES nor in those that received large quantities of HES alone. Histopathological exam. ination of biopsy and autopsy material demonstrated no changes which could be related to hydroxyethyl starch.
\end{abstract}

Cryoprotective agents used in freeze preservation of whole blood can be divided into two major groups: those that protect by intracellular mechanisms and those that are primarily extracellular in action. ${ }^{18}$ The intracellular agents, glycerol $4,7,9,13,20,22,23,24$ and DMSO,8, 16 have been shown to produce a satisfactory degree of cryoprotection. These substances must be thoroughly removed postthaw by washing. Hydroxyethyl starch (HES) is a plasma expander similar to Dextran and PVP1, 5, 10, 14, 25 and is an extracellular cryoprotective agent. 12 It is considered nontoxic $^{2,}$ 6, 19 and nonallergenic. ${ }^{3,17}$ However, HES protected blood may be washed without adverse effects. ${ }^{11}$

Received for publication February 3, 1973; accepted October 1, 1973.
This paper describes coagulation studies performed upon shocked monkeys transfused with the frozen-thawed blood protected by low molecular weight HES. Certain authors ${ }^{10,14,27}$ have reported alterations in coagulation mechanisms during the administration of hydroxyethyl starch of high molecular weight $(200,000$ or greater). Studies were done on the blood of two monkeys infused with large amounts of 12 per cent HES solution alone. We have shown (unpublished data) that the degree of protection afforded the erythrocytes by "low" molecular weight starch was equal to or slightly better than that of the high molecular weight (plasma expander type) HES. The inherent viscosity of the high molecular weight material was higher $(0.3 \mathrm{dl} / \mathrm{g})$ than the $0.15 \mathrm{dl} / \mathrm{g}$ viscosity of the low molecular weight starch. The degree of substitution was the same however, in the range of $0.7=0.8 \mathrm{DS}$. The degree of substitution is directly related to the rate of degradation in the blood stream. ${ }^{10}$

\section{Methods}

Thirteen monkeys were anesthetized and the femoral artery and vein were cannulated with polyethylene catheters connected to a Sanborn multichannel recorder which monitored arterial and venous pressure. Blood equal to 30 to 50 per cent of the blood volume was removed from each monkey in order to lower the systolic pressure to at least $60 \mathrm{~mm}$ of mercury at which point the monkeys had tachycardia and tachypnea. The amount of blood and HES transfused varied according to the weight of the 
animals. In general, the volume replaced equalled the amount withdrawn (i.e., 30 to 50 per cent of the calculated blood volume.) In the blood transfused, there was 14 per cent hydroxyethyl starch by weight. This quantity of hydroxethyl starch was somewhat greater than that used in previous studies with HES as a volume expander.10 The HES percentage was obtained by adding $35 \mathrm{ml}$ of a 40 per cent solution of the starch in normal saline to 65 $\mathrm{ml}$ whole blood and the resultant hematocrit levels were in the range of 20 to 27 per cent. The blood with HES was prepared in $55 \mathrm{ml}$ aliquots. Seven monkeys received homologous blood previously frozen with 14 per cent hydroxyethyl starch solution. The blood-HES mixture was transfused after thawing without washing. Six monkeys were transfused with autologous blood withdrawn during the experiment in sterile ACD vacuum bottles, processed with HES, frozen in liquid nitrogen, and thawed while the animal was in the shocked state.

Kidney and liver biopsy specimens were obtained before and after the transfusions with HES. The lower molecular weight HES used in these studies had a molecular weight of 28,000 to 45,000 . Four animals used as histopathological controls were exsanguinated, their blood frozen for homologous transfusions, and the animals were autopsied. Sections of kidney, lung, lymph nodes, spleen, and liver were examined. Formalin and alcohol fixed tissues were stained with hematoxylin and eosin and with periodic acid-Schiff (PAS) with and without diastase digestion. The rationale for using PAS stain with alcohol fixation to locate HES was based on the work by Mowry and Millican21 who used the method to demonstrate Dextran in mouse tissues.

Whole blood hemoglobin, plasma hemoglobin, hematocrit, per cent red blood cell recovery, red cell saline stability, and potassium levels were determined for each aliquot of monkey donor blood prior to transfusion. Renal function studies (serum creatinine, blood urea nitrogen, and urinalysis) were done for all animals prior to shock, one hour after transfusion and at intervals up to 48 hours.

Coagulation studies were done prior to shock, during the shock phase, at one hour, 24 and 48 hours posttransfusion. The studies obtained were: a platelet count utilizing phase microscopy, quantitative fibrinogen by tyrosine assay, total protein, one stage prothrombin time, par. tial thromboplastin time (PTT), thrombin clotting time (TGT), and euglobulin lysis. Except for the platelet counts, these were done on frozen thawed plasma. In addition, thrombin clotting times and euglobulin lysis times were obtained on fresh blood.

To further study changes in coagulation caused by hydroxyethyl starch itself, two animals were bled of $1 / 4$ to $1 / 3$ of their estimated blood volumes. While these two monkeys were in the shocked state, an amount of 12 per cent HES in saline equal to the amount of blood removed was infused. In these animals, prothrombin consumption tests and platelet factor III assays were obtained as well as those tests listed above.

\section{Results}

Table 1 shows coagulation data obtained from the monkeys in shock transfused with HES-preserved blood. This table includes both the homologous and autologous blood transfusions as there appeared to be no difference in the values obtained. The pretransfusion data was obtained while the monkey was in shock just prior to the administration of the HES preserved blood. There was a lowering of the mean fibrinogen level one hour after transfusion with a return to high levels at 24 hours. The platelet counts showed a mild decrease. In one monkey, platelets decreased to $70,000 /$ $\mathrm{mm}^{3}$ pretransfusion and in one at 24 hours the platelet count was $92,000 / \mathrm{mm}^{3}$ Prolongation of the prothrombin time was noted at one hour after transfusion with a return to normal in 24 hours. The decrease in the total protein appeared to be of the same magnitude as the degree of lowering seen in the fibrinogen assays. At one hour posttransfusion, the PTT appeared slightly prolonged and all returned to normal at 24 hours. Thrombin clotting time was normal or shortened in seven of 13 monkeys at one hour posttransfusion. In the other six monkeys, prolonged TCT's were seen. In the monkeys with the prolonged TCT, the partial thromboplastin time and one stage prothrombin time were also prolonged. Euglobulin lysis time showed insignificant shortening in about half of the monkeys. Only one monkey had a lysis time of $\mathbf{3 0}$ minutes at 24 hours postinfusion. This monkey did not show any evidence of increased bleeding tendency. At 48 hours, all evidence of increased euglobulin lysis had disappeared.

Table 2 lists the results of studies obtained after transfusing two monkeys with a 12 per cent solution of low molecular weight $\mathrm{HES}$ to replace an amount equivalent to approximately $1 / 4$ or $1 / 3$ of their blood volume. The prothrombin consumption studies are within nor- 
TABLE 1. Coagulation Studies in 13 Shorked Monkeys Transfused with Hes-Preserved Blood

\begin{tabular}{|c|c|c|c|c|}
\hline Test & Preshock & Pretransfusion & $\begin{array}{c}\text { Posttransfusion } \\
1 \text { Hour }\end{array}$ & $\begin{array}{l}\text { Posttransfusion } \\
20-24 \text { Hours }\end{array}$ \\
\hline $\begin{array}{l}\text { Fibrinogen } \\
\quad(\mathrm{mg} / 100 \mathrm{ml})\end{array}$ & $\begin{array}{c}374^{*} \\
(265-590) \dagger\end{array}$ & $\begin{array}{c}318 \\
(288-590)\end{array}$ & $\begin{array}{c}214 \\
(155-390)\end{array}$ & $\begin{array}{c}413 \\
(276-576)\end{array}$ \\
\hline $\begin{array}{l}\text { Platelets } \\
10^{3} \mathrm{~mm}^{3}\end{array}$ & $\begin{array}{c}465 \\
(320-660)\end{array}$ & $\begin{array}{c}348 \\
(70-560)\end{array}$ & $\begin{array}{c}254 \\
(150-405)\end{array}$ & $\begin{array}{c}297 \\
(92-505)\end{array}$ \\
\hline $\begin{array}{l}\text { One-stage } \\
\text { prothrombin } \\
\text { time (sec) }\end{array}$ & $\begin{array}{c}11.4 \\
(9.6-14.0)\end{array}$ & $\begin{array}{c}11.3 \\
(10.8-16.0)\end{array}$ & $\begin{array}{c}16.7 \\
(11-27)\end{array}$ & $\begin{array}{c}11.7 \\
(10-14)\end{array}$ \\
\hline $\begin{array}{l}\text { Total } \\
\text { protein } \\
(\mathrm{g} / 100 \mathrm{ml})\end{array}$ & $\begin{array}{c}6.4 \\
(5.4-7.6)\end{array}$ & $\begin{array}{c}5.4 \\
(4.8-6.3)\end{array}$ & $\begin{array}{c}4.0 \\
(3.2-5.3)\end{array}$ & $\begin{array}{c}5.5 \\
(4.3-6.2)\end{array}$ \\
\hline PTT & $\begin{array}{c}42 \\
(28-59)\end{array}$ & $\begin{array}{c}46 \\
(32-63)\end{array}$ & $\begin{array}{c}56 \\
(49-67) \\
(180 \text { sec. for } \\
1 \text { monkey) }\end{array}$ & $\begin{array}{c}39 \\
(39-54)\end{array}$ \\
\hline TCT & $\begin{array}{c}37 \\
(20-53)\end{array}$ & $\begin{array}{c}37 \\
(18-63)\end{array}$ & $\begin{array}{c}(16-25) \\
\text { (in } 7 \text { monkeys) } \\
(48-180) \\
\text { (in } 6 \text { monkeys) }\end{array}$ & $\begin{array}{c}29 \\
(16-52)\end{array}$ \\
\hline
\end{tabular}

- Mean.

† Range.

mal limits. A dilutional effect with a mild decrease in total protein and fibrinogen, and a slight prolongation of the one stage prothrombin time and the PTT were noted. No changes were noted in thrombin clotting time or euglobulin lysis.

Table 3 lists the mean values of studies done on animals that received autologous transfusions and Table 4 lists the mean values of studies done on monkeys receiving homologous transfusions. These studies were obtained prior to shock, one hour posttransfusion and 20 hours posttransfusion. The blood was transfused without post thaw washing, and there was a mean elevation up to $85 \mathrm{mg} / 100 \mathrm{ml}$ in the plasma hemoglobin in the animals receiving autologous blood and $206 \mathrm{mg} / 100 \mathrm{ml}$ in the group receiving homologous blood. Infusion of blood frozen with any cryoprotective agent will result in postthaw levels of plasma hemoglobin ranging from 200 to $900 \mathrm{mg} / 100 \mathrm{ml} .13,23$ This hemoglobin may be reduced by postthaw washing before transfusion to levels in the range of 100 to $200 \mathrm{mg} / 100 \mathrm{ml}$ or less. 22 No hemoglobinuria was noted in either group. The creatinine levels were elevated temporarily and the serum potassium was essentially unchanged. Blood urea nitrogen was elevated minimally at
48 hours in both groups. However, at the end of four days, all values had returned to normal.

Histopathological studies in the four control animals disclosed rather extensive preexisting disease. All of them had birefringent particles, possibly silica, in the lungs and two of them had acute pneumonia. In another animal, liver necrosis was noted as well as PAS positive material in spleen, liver, and lymph nodes with and without diastase digestion with formalin fixed tissues. No other significant findings were noted except for occasional phagocytes which contained PAS positive material. Biopsies of liver and kidney from preshock test monkeys were also used as controls.

Liver and kidney biopsies were obtained after transfusion at various times on six of the test animals that received homologous blood HES transfusion and no consistent differences were noted between controls and test animals.

\section{Discussion}

The coagulation data obtained on the shocked monkeys given blood preserved with hydroxyethyl starch revealed no consistent or significant difference between 
TABle 2. Coagulation Studies in Two Monkeys Given 12 Per Cent Hes Replacing $1 / 4$ to $1 / 3$ of Their Blood Volume

\begin{tabular}{|c|c|c|c|c|c|c|c|c|c|}
\hline \multirow{2}{*}{$\frac{\text { Test }}{\text { Monkey }}$} & \multirow[t]{2}{*}{$\begin{array}{l}\text { Control* } \\
\text { Values }\end{array}$} & \multicolumn{2}{|c|}{ Preinfusion } & \multicolumn{2}{|c|}{$\begin{array}{l}\text { Postinfusion } \\
\text { I Hour }\end{array}$} & \multicolumn{2}{|c|}{$\begin{array}{l}\text { Postinfusion } \\
24 \text { Hours }\end{array}$} & \multicolumn{2}{|c|}{$\begin{array}{l}\text { Postinfusion } \\
48 \text { Hours }\end{array}$} \\
\hline & & A & B & $\mathbf{A}$ & $\mathbf{B}$ & A & B & A & B \\
\hline $\begin{array}{l}\text { Prothrombin } \\
\text { consumption \% }\end{array}$ & & 83 & 75 & 85 & 75 & 80 & 74 & 80 & 78 \\
\hline $\begin{array}{l}\text { Platelets } \\
10^{3} \mathrm{~mm}^{3}\end{array}$ & $320-660$ & 515 & 340 & 360 & 232 & 415 & 258 & 474 & 294 \\
\hline $\begin{array}{l}\text { Total protein } \\
\quad(\mathrm{g} / 100 \mathrm{ml})\end{array}$ & $5.0-6.5$ & 5.2 & 5.5 & 4.1 & 4.1 & 5.0 & 4.4 & 5.5 & 5.1 \\
\hline $\begin{array}{l}\text { Fibrinogen } \\
\quad(\mathrm{mg} / 100 \mathrm{ml})\end{array}$ & $200-415$ & 276 & 179 & 199 & 150 & 268 & 199 & 36.3 & 974 \\
\hline $\begin{array}{l}\text { One-stage } \\
\text { prothrombin } \\
\text { time (sec) }\end{array}$ & $10.0-12.6$ & 11.7 & 12.3 & 12.8 & 13.1 & 11.3 & 12.0 & 9.8 & 11.3 \\
\hline $\begin{array}{l}\text { Partial thrombo- } \\
\text { plastin } \\
\text { clotting } \\
\text { time (sec) }\end{array}$ & $27-40$ & 39 & 46 & 50 & 46 & 57 & 56 & 40 & 54 \\
\hline $\begin{array}{l}\text { Thrombin } \\
\text { clotting } \\
\text { time (sec) }\end{array}$ & $23-43$ & 25 & 52 & 26 & 28 & 25 & 28 & 20 & 21 \\
\hline $\begin{array}{l}\text { Euglobulin } \\
\text { lysis }\end{array}$ & $5 \mathrm{hr}$. & None & None & None & None & None & None & None & None \\
\hline
\end{tabular}

- Previously established from ten normal monkeys.

homologous and autologous blood transfusion. The lowering of the total protein, fibrinogen and platelets is consistent with dilution; there was some increase in the mean fibrinogen at 48 hours. Others have observed similar coagulation changes following Dextran and high molecular weight hydroxyethyl starch infusion. ${ }^{15}$

TABLE 3. Results of Tests Obtained on Six Monkeys Receiving Autologous Transfusions

\begin{tabular}{|c|c|c|c|c|}
\hline Test & Preshock & $\begin{array}{c}\text { Posttransfusion } \\
1 \text { Hour }\end{array}$ & $\begin{array}{c}\text { Posttransfusion } \\
20 \text { Hours }\end{array}$ & $\begin{array}{c}\text { Posttransfusion } \\
48 \text { Hours }\end{array}$ \\
\hline Blood urea & & & & \\
\hline $\begin{array}{l}\text { Nitrogen } \\
(\mathrm{mg} / 100 \mathrm{ml})\end{array}$ & $\begin{array}{c}16^{*} \\
(12-20) \dagger\end{array}$ & $\begin{array}{c}21 \\
(16-26)\end{array}$ & $\begin{array}{c}28 \\
(17-48)\end{array}$ & $\begin{array}{c}31 \\
(27-44)\end{array}$ \\
\hline $\begin{array}{l}\text { Creatinine } \\
\qquad(\mathrm{mg} / 100 \mathrm{ml})\end{array}$ & $\begin{array}{c}1.2 \\
(0.9-1.4)\end{array}$ & $\begin{array}{c}1.5 \\
(0.9-1.9)\end{array}$ & $\begin{array}{c}1.6 \\
(1.1-1.8)\end{array}$ & $\begin{array}{c}1.3 \\
(1.0-1.5)\end{array}$ \\
\hline $\begin{array}{l}\text { Serum } \\
\text { potassium } \\
(\text { meq } / 1)\end{array}$ & $\begin{array}{c}4.7 \\
(4.0-5.1)\end{array}$ & $\begin{array}{c}4.5 \\
(3.5-4.9)\end{array}$ & $\begin{array}{c}4.8 \\
(3.7-5.2)\end{array}$ & $\begin{array}{c}4.6 \\
(4.3-4.7)\end{array}$ \\
\hline $\begin{array}{l}\text { Plasma } \\
\text { hemoglobin } \\
\quad(\mathrm{mg} / 100 \mathrm{mI})\end{array}$ & $\begin{array}{c}10.8 \\
(5.4-22.8)\end{array}$ & $\begin{array}{c}85 \\
(55.8-123.3)\end{array}$ & $\begin{array}{c}32.2 \\
(10.6-84.5)\end{array}$ & $\begin{array}{c}10 \\
(3.1-21.5)\end{array}$ \\
\hline
\end{tabular}

- Mean.

+ Range. 
Table 4. Results of Tests on Seven Monkeys Receiving Homologous Transfusions

\begin{tabular}{|c|c|c|c|c|}
\hline Test & Preshock & $\begin{array}{c}\text { Posttransfusion } \\
1 \text { Hour }\end{array}$ & $\begin{array}{l}\text { Posttransfusion } \\
20 \text { Hours }\end{array}$ & $\begin{array}{c}\text { Posttransfusion } \\
48 \text { Hours }\end{array}$ \\
\hline \multicolumn{5}{|l|}{ Blood urea } \\
\hline $\begin{array}{l}\text { Nitrogen } \\
(\mathrm{mg} / 100 \mathrm{ml})\end{array}$ & $\begin{array}{c}20^{*} \\
(14-34) \dagger\end{array}$ & $\begin{array}{c}24 \\
(19-37)\end{array}$ & $\begin{array}{c}30 \\
(21-38)\end{array}$ & $\begin{array}{c}30 \\
(15-41)\end{array}$ \\
\hline $\begin{array}{l}\text { Creatinine } \\
\quad(\mathrm{mg} / 100 \mathrm{ml})\end{array}$ & $\begin{array}{c}1.4 \\
(1.2-1.8)\end{array}$ & $\begin{array}{c}1.4 \\
(0.9-2.0)\end{array}$ & $\begin{array}{c}1.7 \\
(1.4-2.2)\end{array}$ & $\begin{array}{c}1.4 \\
(1.2-1.5)\end{array}$ \\
\hline $\begin{array}{l}\text { Serum } \\
\text { potassium } \\
\text { (meq/1) }\end{array}$ & $\begin{array}{c}3.4 \\
(3.0-3.7)\end{array}$ & $\begin{array}{c}3.6 \\
(2.6-5.2)\end{array}$ & $\begin{array}{c}4.3 \\
(3.2-6.4)\end{array}$ & $\begin{array}{c}4.1 \\
(3.4-5.0)\end{array}$ \\
\hline $\begin{array}{l}\text { Plasma } \\
\text { hemoglobin } \\
(\mathrm{mg} / 100 \mathrm{ml})\end{array}$ & $\begin{array}{c}14.8 \\
(6-22)\end{array}$ & $\begin{array}{c}206 \\
(92-362)\end{array}$ & $\begin{array}{c}34.6 \\
(12.9-52)\end{array}$ & $\begin{array}{c}17.5 \\
(10.2-27.4)\end{array}$ \\
\hline
\end{tabular}

- Mean.

+ Range.

In the two monkeys given 12 per cent HES solution to replace their blood volume, no abnormality was observed in platelet factor III. We did not study the prothrombin consumption at four or eight hours posttransfusion, and it is possible that some platelet abnormalities could have been present at that time. However, none of the monkeys demonstrated any bleeding tendency or wound oozing. The reason for prolongation of TCT in some animals is not clear. The HES may interfere with thrombin fibrinogen interaction. This could explain the prolongation of some of these coagulation tests in our shocked animals. The action on the coagulation mechanisms may depend upon the concentration of the HES present in the blood. There was no evidence of heparinoid action by this agent and abnormalities were not corrected by the addition of protamine in vitro.

In similar experıments using polyvinyl pyrrolidone as the cryoprotective material,26 we observed hemoglobinuria that persisted for the first 24 hours. In the animals gives the HES-blood mixture, no hemoglobinuria was detected in any of the monkeys.

Creatinine levels were elevated as noted at one and 20 hours but returned to nor- mal levels within 48 hours. Acute renal damage did not occur. The modest elevation of the blood urea nitrogen can be attributed to hypovolemic induced changes in the animals. The elevations were not striking and were temporary. Similarly, serum potassium levels were not changed significantly. As expected, an elevation of plasma hemoglobin occurred one hour after transfusion. Within 24 hours, this had decreased and at 48 hours it had returned to preshock levels. The plasma hemoglobin levels were highest in the animals receiving homologous blood. We did not do compatibility studies for these transfusions.

It is difficult to evaluate the tissue change seen because of the variability of the findings. For example, liver necrosis was present in controls as well as test animals. Two animals died rather acutely, one because of fluid overload and the second because of insufficient blood replacement. Two other monkeys were sacrificed. PAS positive material was inconstantly seen in macrophages and epithelial cells in liver, spleen, and kidney in both control and test animals.

Mowry and Millican ${ }^{21}$ have demonstrated PAS positive material in various organs after Dextran infusion up to three months 
following transfusion. In this study, PAS postive material was noted in macrophages in both control material and test animals so there was no evidence that HES of low molecular weight persists in tissues. There was no consistent histopathological changes that could be related to the presence of HES in the blood transfused.

\section{Acknowledgments}

This study was supported in part by the Office of Naval Research, Contract ONR-na-5-71. The authors thank Dr. John Penner, Professor, Department of Internal Medicine, Simpson Memorial Institute, University of Michigan, for his advice and assistance with the coagulation studies. The hydroxyethyl starch used in this study was provided by McGaw Laboratories, Division of American Hospital Supply Corporation, Glendale, California.

\section{References}

1. Ballinger, W. F. II, G. F. Murray, and E. E Morse: Preliminary report on the use of hydroxyethyl starch solution in man. J. Surg. Res. 6: 180, 1966.

2. ——, T. F. Solanke, and W. I. Thompson: The effect of hydroxyethyl starch upon survival of dogs subjected to hemorrhagic shock. Surg. Gynecol. Obstet. 122: 33, 1966.

3. Brickman, R. D., G. F. Murray, W. L. Thomp. son, and W. F. Ballinger, II: The antigenicity of hydroxyethyl starch in humans. JAMA 198: 1277,1966 .

4. Doebbler, G. F., and A. P. Rinfret: The influence of protective compounds and cooling and warming conditions on hemolysis of erythrocytes by freezing and thawing. Biochim. Biophys. Acta 58: 449, 1962.

5. Farrow, S. P., M. Hall, and C. R. Ricketts: Changes in the molecular composition of circulating hydroxyethyl starch. Br. J, Pharmacol. 38: 725, 1970.

6. Gollub, S., D. C. Schechter, T. Hirose, and C. P. Bailey: Use of hydroxyethyl starch solution in extensive surgical operations. Surg. Gynecol. Obstet. 128: 725, 1969.

7. Haynes, L. L., J. L. Tullis, H. M. Pyle, M. T. Sproul, S. Wallach, and W. C. Turville: Clinical use of glycerolized frozen blood. JAMA 173: $1657,1960$.

8. Huggins, C. E.: Prevention of hemolysis of large volumes of red blood cells slowly frozen and thawed in the presence of dimethylsulfoxide. Transfusion 8: 483, 1963.

9. ——: Frozen blood: theory and practice. JAMA 198: 941, 1965.
10. Karlson, K. E., A. Garzon, G. W. Shaftan, and C. Chu-Jeng: Increased blood loss associated with administration of certain plasma expanders: dextran 75, dextran 40, and hydroxyethyl starch. Surgery 62: 670, 1967.

11. Knorpp, C. T., W. H. Starkweather, H. H. Spencer, and $L$. Weatherbee: The preserva. tion of erythrocytes at liquid nitrogen temperatures with hydroxyethyl starch: the removal of hydroxyethyl starch from erythrocytes after thawing. Cryobiology 8: 511, 1971.

12. —, W. R. Merchant, P. W. Gikas, H. H. Spencer, and N. W. Thompson: Hydroxyethyl starch: Extracellular cryophylactic agent for erythrocytes. Science 157: 1812, 1967.

13. Krijnen, H. W., J. J. Fr. M. DeWit, A. C. J. Kuivenhoven, J. A. Loos, and H. K. Prins: Glycerol treated human red cells frozen with liquid nitrogen. Vox. Sang. 9: 559, 1964.

14. Lee, W. H., Jr., N. Cooper, M. G. Weidner, Jr., and E. S. Murner: Clinical evaluation of a new plasma expander, hydroxyethyl starch. J. Trauma 8: 381, 1968.

15. Lewis, J. H., I. L. F. Szeto, W. L. Bayer, M. Takaori, and P. Safar: Severe hemodilution with hydroxyethyl starch and dextrans. Arch. Surg. 93: 941, 1966.

16. Lovelock, J. E., and M. W. H. Bishop: Prevention of freezing damage to living cells by dimethyl sulfoxide. Nature 183: 1994, 1959.

17. Maurer, P. H., and B. Berardinelli: Immuno logic studies with hydroxyethyl starch (HES), a proposed plasma expander. Transfusion 8: $265,1968$.

18. Meryman, H. T.: Cryoprotective agents. Cryobiology 8: 173, 1971.

19. Metcalf, W., A. Papadopoulos, R. Tufaro, and A. Barth: A clinical physiologic study of hydroxyethyl starch. Surg. Gynecol. Obstet. 131: 255, 1970.

20. Pert, J. H., R. Moore, and P. K. Schork: Report on more recent developments with glycerolsucrose procedures. In Proceedings of $\mathrm{Na}$ tional Academy of Sciences-National Research Council Conference on Long Term Preservation of' Red Blood Cells. 1965, p. 212.

21. Mowry, R. W., and R. C. Millican: A histochemical study of the distribution and fate of dextran in tissues of the mouse. Am. J. Pathol. 29: 523, 1953.

22. Rapatz, G., and B. Luyet: Effects of cooling rates on preservation of erythrocytes in frozen blood containing various protective agents. Biodynamica 9: 333, 1965.

23. Rowe, A. W., J. B. Derrick, W. Miles, F. H Allen, and A. Kellner: Transfusion of blood frozen by the low glycerol-rapid freeze process. Bibl. Haematol., 38, Part II, 320, 1971. 
24. Smith, A. U.: Prevention of haemolysis during freezing and thawing of red blood cells. Lancet 259: 910, 1950.

25. Solanke, T. F.: Clinical trial of six per cent HES in 19 patients. West Afr. Med. J. 17: 242, 1968.

26. Thompson, N. W., C. T. Knorpp, P. W. Gikas, and $W$. R. Merchant: Multiple unit transfusion of frozen thawed whole blood in the shocked monkey. Proc. 10th Cong. Int. Soc. Blood Transf., Stockholm, 1964. Bibl. Haemat. No. 23, part 1-3 Krager, Bosel, 1965. p. 719 .

27. Thompson, W. L., and R. H. Gadsden: Pro longed bleeding times and hypofibrinogenemia in dogs after infusion of hydroxyethyl starch and dextran. Transfusion 5: 440, 1965.
28. —, and R. P. Walton: Blood changes, renal function and tissue storage following massive infusions of hydroxyethyl starches. Fed. Proc. 22: $640,1963$.

L. Weatherbee, M.D., Chief Laboratory Service.

H. H. Spencer, M.D., Chief of Staff.

C. T. Knorpp, M.S.

S. M. Lindenauer, M.D., Chief Surgical Service, Veterans Administration Hospital, 2215 Fuller Road, Ann Arbor, Mich. 48105.

P. W. Gikas, M.D., Professor, Department of Pathology.

N. W. Thompson, M.D., Professor, Department of Surgery, Ininersity of Michigan Medical (ienter, 1105 E. Ant, Ann Arbor, Mich. 48104.

\section{Announcement}

The National. Heart and Lung Institute announces the availability of Individual $\mathrm{Re}$ search Fellowship Awards for postdoctoral training in basic biomedical sciences and research in clinical specialties related to certain areas of programmatic interest as identified in the National Heart, Blood Vessel, Lung and Blood Program.*

In addition to supporting fellowship awards in heart, vascular and lung diseases, the Bureau seeks particularly to support individual fellowship awards in the areas of hemophilia and clotting proteins, thrombosis (thromboembolic disorders, microcirculatory thrombosis), platelets, hemocompatible materials, hemoglobin and hemoglobinopathies, RBC enzymes and membranes, transplantation biology, blood banking sciences (blood factionation and pres ervation, hepatitis, blood safety, immunohematology) and artificial blood.

In the broad area of blood clotting abnormalities, there is particular interest in hemophilia, plasma clotting and lysing proteins, genetic control mechanisms, platelet structure, function and regulation, the role of microcirculatory thrombosis and methods of this study, the relation of thrombosis to atherosclerosis and the basic mechanisms involved in the process of thrombosis. Closely related to this are studies concerned with the interaction between blood components and synthetic surfaces at a molecular level.

- Individual copies are available on request.
Of the many aspects of red cell research, hemoglobins and hemoglobinopathies are considered target areas. The molecular aspects of hemoglobin structure, function and regulation are of particular interest. Further research also is needed in red cell enzyme systems and red cell membrane structure and function.

Blood banking science also is a major target area. In addition to basic studies of mechanisms involved in preservation of cellular elements, research into fractionation techniques, transfusion related hepatitis, and immunohematology require additional impetus.

In the related area of transportation biology, the Institute will support research training in immunogenetics, organ preservation and the pathophysiology of the posttransplant state.

Applications will be reviewed and awards administered in accordance with the information presented in the NIH Guide for Grants and Contracts, Volume 2, No. 10, November 30, 1973. Deadline for receipt of applications is May 1, 1974. Application material may be obtained from the Office of Research Manpower, Division of Research Grants, National Institutes of Health, Bethesda, Maryland 20014. For further information regarding programs of the Division, contact:

Dr. Harvey Klein

Division of Blood Diseases and Resources

Building 31, Room 4A-04

National Heart and Lung Institute

National Institutes of Health

Bethesda, Maryland 20014 